\title{
Obituaries
}

Obituaries should be submitted by email to Kate Maynard at k.maynard@nature.com.

All submitted obituaries should be 350 words maximum in length (apart from obituaries for past presidents of the BDA where the length should be $700-800$ words).

Content of the obituary is down to the individual author, and the approval of the family should be given for the obituary prior

to submission to the $B D J$.

\section{IAN KENNETH MACLEOD}

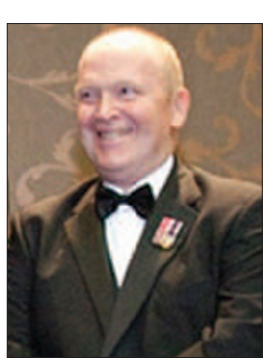

Former President of the Dental Technologists Association (DTA) Ian Kenneth MacLeod died on 20 August 2011, aged 59. His funeral was held on 26 August and DTA

President John Stacey attended along with previous presidents, Tony Griffin and Paul Mallett.

Ian had a lifelong commitment to team dentistry and was best known for his expert handling of initial negotiations with the GDC over the introduction of registration for dental care professionals.

Ian spent a long period working as a dental and maxillofacial technologist in the RAF Dental Branch before leaving to work at Walsall Manor Hospital. Following a stint in the Lake District, Ian joined University Dental Hospital Manchester as Dental Laboratories Technical Manager. He was committed to developing dental technology as a professional career and helped develop National Occupational Standards.

Having previously been awarded the prestigious Dennison Award from his peers in dentistry, Ian received an MBE in the 2001 Queen's Birthday Honours List for his services to dental care. Then in 2010 he was honoured by the DTA with a Fellowship in recognition of his lifetime of commitment to dental technology.

Ian was active in gaining support for the charity Mission Cure Bangladesh in their quest to set up a specialist centre for head and neck cancer, and a maxillofacial trauma centre.
As head of the dental laboratories at Dental Hospital Manchester Ian facilitated their refurbishment and update. He also actively encouraged the integration of real work skill development activities between the dental technology courses at Manchester Metropolitan University and the education of dentists at the University Dental Hospital Manchester.

Outside of work Ian's immaculate MG sports car was his pride and joy and taking her for a ride over the moorland roads was a great treat for him. The onset of an aggressive cancer cut short his plans, although he fought hard and bravely to live out the year that he had and to give more care to others.

Ian is survived by his wife Julia, his mother Jean, his daughter Gail and son Keith, and his grandchildren of whom he was so proud.

Tony Griffin

\section{RUSS STEWARD}

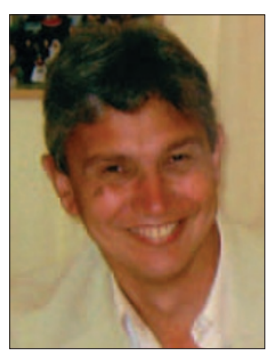

Russ was born in Norwich in November 1955. His father was an army major; Russ consequently spent his formative years in a number of locations. His education began

in Winchester and was completed at Stratford Grammar School. He commenced University in Birmingham in 1975, qualifying in 1979. He was an immensely popular student and a genuine sporting all-rounder, representing both the dentists and the university in a number of sports. Of particular note was lacrosse. Prior to university he had never played the sport, but with two weeks' practice, he was selected for the university first team.

On qualification, Russ spent a year doing oral surgery at East Birmingham Hospital before going into practice in Acocks Green in South Birmingham in 1981; he became a partner 12 months later.

His sporting prowess continued and he was a highly competent golfer and an exceptionally good skier, gaining the French advanced skiing qualification.

In everything he did, he set himself the highest standards and always prepared himself meticulously for any challenges that lay ahead.

Russ has been a stalwart of Birmingham LDC since 1986. There had been an 'old guard' who had come to treat the LDC as an old boys' club, unaccountable; Russ and others decided to depose those they felt worked for themselves and not the interests of their constituents. It was a philosophy Russ confirmed with his years of service to the LDC as Chair and Treasurer.

Russ was often forceful in meetings, not accepting waffle and able to see through anyone who really did not believe what they were saying. But he was never rude or lost his temper, he surgically won arguments. He chose to stand again at the election last March despite his ongoing illness; this delighted everyone and he was re-elected as he had been many times before, confirming how important he still thought his responsibility - but sadly his health worsened.

Russ is a man who will never be replaced in Birmingham dental politics and a huge influence on many both as a professional and in doing the right thing.

Eddie Crouch Peter Casasola 